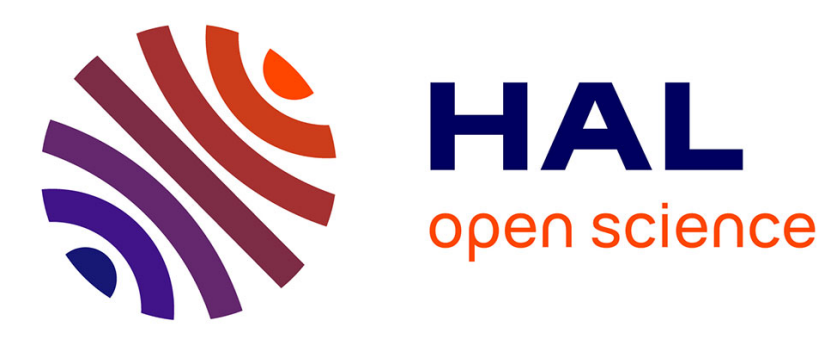

\title{
Flexible Nanoholey Patches for Antibiotic-Free Treatments of Skin Infections
}

\author{
Chengnan Li, Ran Ye, Julie Bouckaert, Amaia Zurutuza, Djamel Drider, \\ Tetiana Dumych, Solomiya Paryzhak, Volodymyr Vovk, Rostyslav O. Bilyy, \\ Sorin Melinte, et al.
}

\section{To cite this version:}

Chengnan Li, Ran Ye, Julie Bouckaert, Amaia Zurutuza, Djamel Drider, et al.. Flexible Nanoholey Patches for Antibiotic-Free Treatments of Skin Infections. ACS Applied Materials \& Interfaces, 2017, 9 (42), pp.36665-36674. 10.1021/acsami.7b12949 . hal-01716582

\section{HAL Id: hal-01716582 https://hal.science/hal-01716582}

Submitted on 23 Feb 2018

HAL is a multi-disciplinary open access archive for the deposit and dissemination of scientific research documents, whether they are published or not. The documents may come from teaching and research institutions in France or abroad, or from public or private research centers.
L'archive ouverte pluridisciplinaire HAL, est destinée au dépôt et à la diffusion de documents scientifiques de niveau recherche, publiés ou non, émanant des établissements d'enseignement et de recherche français ou étrangers, des laboratoires publics ou privés. 


\section{Flexible Nanoholey Patches for Antibiotic-Free Treatments of Skin Infections}

Authors: Chengnan Li†‡\#, Ran Ye§\#, Julie Bouckaertll, Amaia Zurutuza $\perp$, Djamel Dridern, Tetiana Dumych $\boldsymbol{\Delta}$, Solomiya Paryzhak $\boldsymbol{\Delta}$, Volodymyr Vovk $\boldsymbol{\Delta}$, Rostyslav O. Bilyy $\boldsymbol{\Delta}$, Sorin Melinte $\S$, Musen Li $\ddagger$, Rabah Boukherroub*†, and Sabine Szunerits*†

${ }^{\dagger}$ Université de Lille, CNRS, Centrale Lille, ISEN, Université de Valenciennes, UMR 8520IEMN, F-59000 Lille, France

$¥$ Key Laboratory for Liquid-Solid Structural Evolution and Processing of Materials (Ministry of Education), Shandong University, Jinan 250061, China

$\S$ Institute of Information and Communication Technologies, Electronics and Applied Mathematics, Université catholique de Louvain, 1348 Louvain-la-Neuve, Belgium " Unité de Glycobiologie Structurale et Fonctionnelle (UGSF), UMR 8576 du CNRS et Université de Lille, 50 Av. de Halley, 59658 Villeneuve d'Ascq, France

${ }^{\perp}$ Graphenea S.A., Tolosa Hiribidea 76, 20018 Donostia, San Sebastian, Spain

- Institut Charles Viollette, Université de Lille1, EA 7394 Lille, France

^ Danylo Halytsky Lviv National Medical University, 79010 Lviv, Ukraine

First published: 28/09/2017

DOI: $10.1021 /$ acsami.7b12949

Abstract.

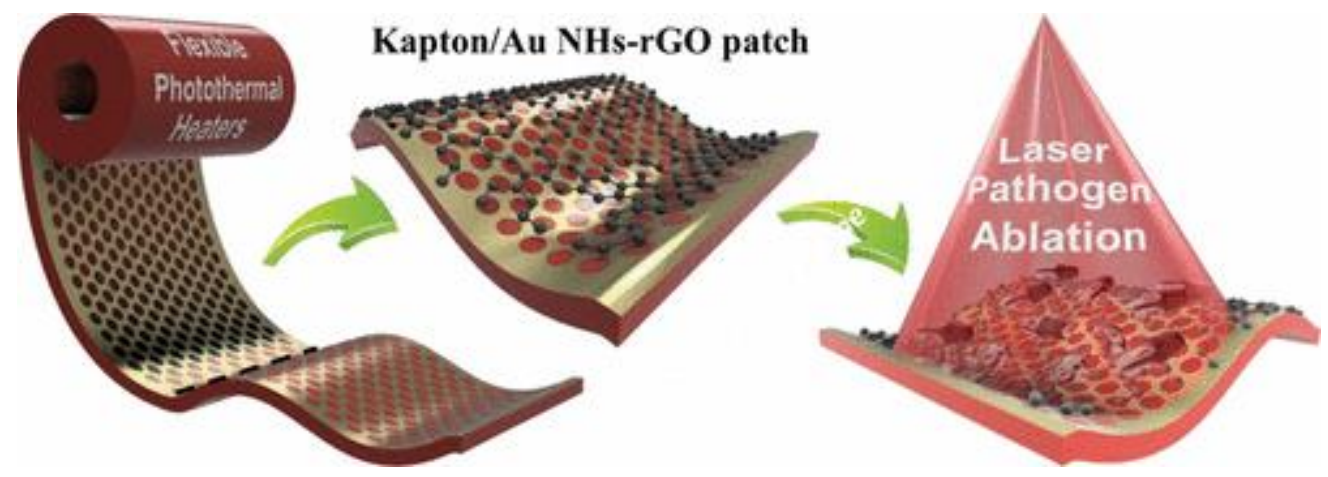

Despite the availability of different antibiotics, bacterial infections are still one of the leading causes of hospitalization and mortality. The clinical failure of antibiotic treatment is due to a general poor antibiotic penetration to bacterial infection sites as well as the development of antibiotic-resistant pathogens. In the case of skin infection, the wound is covered by exudate, making it impermeable to topical antibiotics. The development of a flexible patch allowing a rapid and highly efficient treatment of subcutaneous wound infections via photothermal irradiation is presented here. The skin patch combines the near-infrared photothermal properties of a gold nanohole array formed by self-assembly of colloidal structures on flexible polyimide films with that of reduced graphene oxide nanosheets for laser-gated pathogen inactivation. In vivo tests performed on mice with subcutaneous skin infection and treated with the photothermal skin patch show wound healing of the infected site, while nontreated areas result 1

DOI: 10.1021/acsami.7b12949 - Journal: ACS Appl. Mater. Interfaces - Post-print 
in necrotic muscular fibers and bacterial infiltrate. No loss in efficiency is observed upon multiple use of these patches during in vivo experiments because of their robustness.

Keywords:

bacteria ablation; gold nanoholes; in vivo treatment; photothermal therapy; polyimide; reduced graphene oxide; wound infection

\section{Introduction}

The skin, a complex multilayer organ, provides the largest interface between the human body and the external environment. In the case of skin damage, infected wounds are easily formed, in particular when the wound is not properly treated or when the human healing mechanism fails. $(1,2)$ Current treatment approaches for subcutaneous bacterial abscesses involve incisioninduced wound drainage and administration of high doses of antibiotics intravenously. Since the wound is usually covered with exudate, topical application of antibiotics usually fails. Besides, we have shown that activated neutrophils can form a completely unpermeable barrier around the wound,(3) making superficial wound a hard place to be reached by treatment agents. While the pain associated with incision-based drainage remains a serious complication for the patient, antibiotic administration continues to be challenging due to the lack of vascularity, limiting the access of the drug to the infection site as well as due to the increase in antibioticresistant bacteria. The importance of temperature in the wound-healing process $(4,5)$ as antibiotic alternative for the effective killing of pathogens $\underline{(6-9)}$ has been recognized as a novel way to treat wound infections. Khan et al. investigated for example the direct effect of topical radiation heating using a bandage system with delivery heat at $38^{\circ} \mathrm{C} . \underline{(5)}$ Intermittent heating for $5 \mathrm{~h}$ significantly increased local dermal blood flow in the injured skin and increased, in addition, immunoreactivity. We have shown lately that near-infrared absorbing gold nanorods coated with reduced graphene oxide and modified with a mannose comprising ligands allows for the selective and efficient ablation of Escherichia coli UTI89 in only a few minutes.(7) Rather than using graphene-based derivatives, $(2,10-13)$ or gold nanostructures,(14-17) where large-scale fabrication needs good synthetic skills, we developed in this work a plasmonicbased patch operating in the near-infrared. While free-standing polymer films can adhere strongly to tissue and are useful as medical plasters, $(18,19)$ compared to dispersed gold nanostructures, $(20)$ gold nanoparticle arrays attached to flexible substrates are essentially twodimensional heating sources that can be operated uninterruptedly.(21-24) The presented antibacterial patch is accommodating a polyimide stripe modified by gold nanoholes ( $\mathrm{Au}$ NHs)(25-27) film with strong absorption in the near-infrared (NIR) and postcoated with reduced graphene oxide (rGO) (Figure 1) to increase the light absorption efficiency. Kapton, highly aromatic polyimide resins, praised for its high thermal stability $\left(>300{ }^{\circ} \mathrm{C}\right)$, high tensile strength, and bendability, was chosen due to the attractiveness of this material for a wide range of applications, including soft electronics, (28) materials for membranes, (29) and packaging. The advantage of this presented topical heating dressing compared to classical methods for the thermal treatment of wounds is that heat can be applied extremely locally, limiting side effects on intact skin. Furthermore, while the use NIR lamps will result in temperature increase of some degrees, the proposed patch can in a short time raise solution temperatures by several tens of degrees, where the final temperature can be simply tuned by choosing the right laser power and 
time. Though not discussed in this work, the use of the reduced graphene oxide coatings allows loading of hydrophilic and hydrophobic drugs into the heating patch, which would allow, in addition, the local delivery of therapeutics.

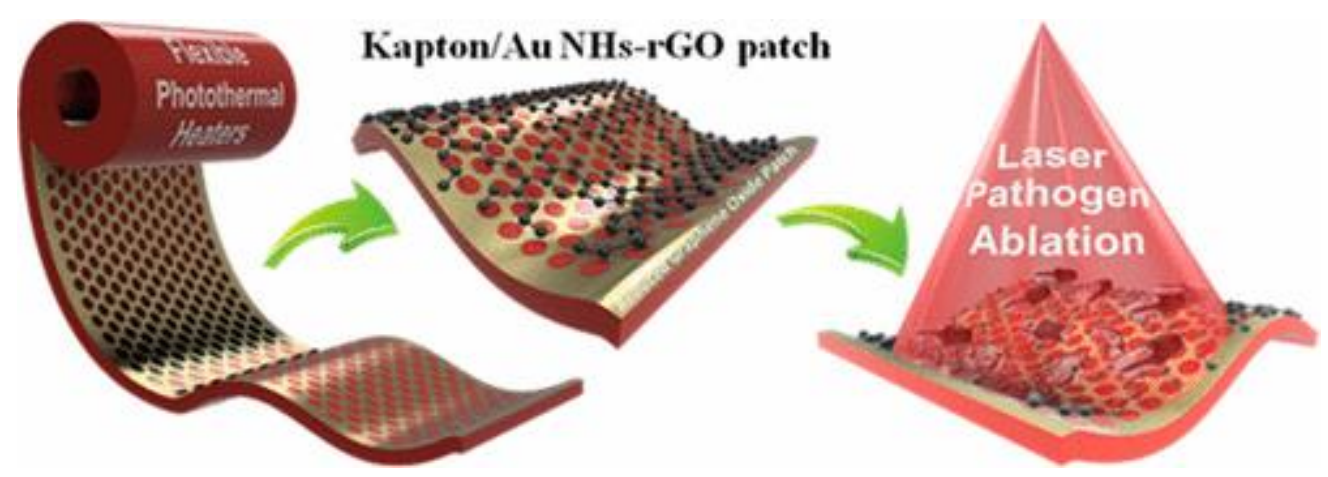

Figure 1. Flexible nanoholey photothermal heaters for the ablation of pathogens. Schematic view of the skin patch concept.

\section{Experimental section}

\subsection{Fabrication of Gold Nanoholes Modified Kapton (K/Au NHs)}

Kapton HN polyimide foils $\left(10 \times 10 \mathrm{~mm}^{2}\right.$, thickness $125 \mu \mathrm{m}$, DuPont $)$ were cleaned with acetone in an ultrasonic water bath for $30 \mathrm{~min}$, followed with isopropanol for $10 \mathrm{~min}$ and then dried under a nitrogen flow. The cleaned Kapton foils were modified with gold nanoholes (K/Au NHs) according to recent publications.(30-32) A monolayer of $980 \mathrm{~nm}$ polystyrene beads (Microparticles $\mathrm{GmbH}$ ) was first deposited on the surface of Kapton by self-assembly. To reduce the size of the particles and isolate them, $\mathrm{SF}_{6}$ and oxygen plasma etching for $11 \mathrm{~min}$ was employed ( 5 mTorr). The samples were coated with $2 \mathrm{~nm}$ Ti followed by $40 \mathrm{~nm} \mathrm{Au}$ at a constant deposition rate of $1 \AA \mathrm{s}^{-1}$ using physical vapor deposition. The beads on top of the Kapton were removed by dissolution in chloroform (overnight). The arrays display holes of an average size of $630 \mathrm{~nm}$ and center-to-center spacing of $980 \mathrm{~nm}$.

\subsection{Preparation of Graphene-Coated K/Au NHs (K/Au NHs-Graphene)}

Graphene formed on polycrystalline $\mathrm{Cu}$ foils was transferred onto K/Au NHs using a modified wet chemical transfer process as reported in the literature.(33) Poly(methyl methacrylate) (PMMA, 5\%) was spin-coated onto the graphene-coated $\mathrm{Cu}$ foil and baked at $170{ }^{\circ} \mathrm{C}$ for 10 min. The $\mathrm{Cu}$ foil was dissolved using a solution of $\mathrm{HCl} / \mathrm{H}_{2} \mathrm{O}_{2} / \mathrm{H}_{2} \mathrm{O}(1 / 1 / 40)$ and the formed graphene/PMMA rinsed with deionized water 5-6 times to remove any ion contamination. Graphene was then mechanically transferred onto K/Au NHs, followed by a slow backing step at $90{ }^{\circ} \mathrm{C}$ to remove trapped water and to increase the contact between graphene and $\mathrm{K} / \mathrm{Au} \mathrm{NHs}$. Finally, the PMMA layer was removed by dipping the sample in acetone for $30 \mathrm{~min}$, rinsed with methanol, and dried by a mild nitrogen blow.

\subsection{Preparation of rGO-Coated K/Au NHs (K/Au NHs-rGO)}


rGO was formed by adding hydrazine hydrate $(100 \mu \mathrm{L}, 6.4 \mathrm{mM})$ to $100 \mathrm{~mL}$ of GO aqueous suspension $\left(3 \mathrm{mg} \mathrm{mL}^{-1}\right)$ in a round-bottom flask and heated in an oil bath at $80{ }^{\circ} \mathrm{C}$ for $24 \mathrm{~h}$. During this time, the reduced GO gradually precipitates out of the solution. The product was isolated by filtration over a polyvinylidene difluoride (PVDF) membrane with a $0.45 \mu \mathrm{m}$ pore size, washed copiously with water $(5 \times 20 \mathrm{~mL})$ and methanol $(5 \times 20 \mathrm{~mL})$, and dried in an oven at $60{ }^{\circ} \mathrm{C}$ for $6 \mathrm{~h}$. An aqueous suspension of $\mathrm{rGO}\left(1 \mathrm{mg} \mathrm{mL}{ }^{-1}, 25 \mu \mathrm{L}\right)$ was drop-casted three times onto $\mathrm{K} / \mathrm{Au} \mathrm{NHs}$ and allowed to dry overnight at $70{ }^{\circ} \mathrm{C}$.

\subsection{Characterization Scanning Electron Microscopy ( SEM)}

Images were obtained using an electron microscope ULTRA 55 (Zeiss) equipped with a thermal field emission emitter and three different detectors (Energy-Selective Backscattered Detector with filter grid, high efficiency In-lens Secondary Electron Detector, and EverhartThornley Secondary Electron Detector).

\section{Absorption Spectra}

Spectra were recorded using a PerkinElmer Lambda UV-vis 950 spectrophotometer in a $1 \mathrm{~cm}$ quartz cuvette. The wavelength range was 200-1100 nm.

\section{Micro-Raman Spectroscopy Measurements}

Measurements were performed on a Horiba Jobin Yvon LabRam high-resolution microRaman system combined with a $473 \mathrm{~nm}(1 \mathrm{~mW})$ laser diode as excitation source. Visible light is focused by a $100 \times$ objective. The scattered light is collected by the same objective in backscattering configuration, dispersed by a $1800 \mathrm{~mm}$ focal length monochromator and detected by a CCD camera.

\section{Measurement of the Photothermal Effect}

All irradiations were performed in standard 24-well plates. A $980 \mathrm{~nm}$ continuous wave laser (Gbox model, Fournier Medical Solution) was used for the photothermal experiments. This laser was injected into a $400 \mu \mathrm{m}$ core fiber and placed around $6 \mathrm{~cm}$ away from the bottom of the wells. The output was not collimated and the resulting beam divergence allowed us to illuminate uniformly the wells. The temperature changes were captured by an infrared camera (Thermovision A40) and treated using ThermaCam Researcher Pro 2.9 software.

\subsection{Bacterial Growth Conditions}

The Gram-negative $\beta$-lactamase-producing LF82 (an adherent-invasive $E$. coli) were grown at $37{ }^{\circ} \mathrm{C}$ with shaking in Luria-Bertani (LB) broth overnight. Upon 100-fold dilution, incubation was prolonged until the $\mathrm{OD}_{600}$ had reached 0.3-0.5. The probiotic Enterococcus faecalis DD14, a Gram-positive commensal recently isolated from the meconium of newborn children at the Central Hospital of Roubaix, France, was grown without shaking overnight at $37{ }^{\circ} \mathrm{C}$, in ManRogosa-Sharpe (MRS) medium purchased from Sigma, Lituania. S. epidermidis, a clinical strain obtained from the Central Hospital of Roubaix, France, was grown in a brain heart infusion (BHI) medium at $37^{\circ} \mathrm{C}$ overnight without agitation.

\subsection{Bacteria Cell Irradiation}

4

DOI: 10.1021/acsami.7b12949 - Journal: ACS Appl. Mater. Interfaces - Post-print 
An aliquot of $1 \mathrm{~mL}$ cultures were seeded in a sterile 24 -well plate at $10^{9} \mathrm{cfu} \mathrm{mL}^{-1}$. The interfaces were immersed into a well of the 24-well plates and irradiated with the laser set at $980 \mathrm{~nm}$ illumination for different time intervals and laser powers $\left(0-5 \mathrm{~W} \mathrm{~cm}^{-2}\right)$.

After this treatment, survival of the bacteria was measured by determining the titer of viable bacteria able to grow. A tenfold dilution series of the bacterial solutions in phosphate buffer saline were spotted in $10 \mu \mathrm{L}$ aliquots on corrresponding agar medium. Visual counting of the number of colonies upon overnight incubation at $37^{\circ} \mathrm{C}$ allowed reading out the initial and final

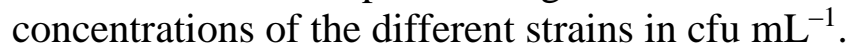

After irradiation, the bacteria were immediately stained for cell viability assays. The total amount of live and dead bacteria cells was determined using the Live/Dead BacLight bacterial viability staining kit (Invitrogen). A 1:1 mixture of SYTO 9 nucleic acid stain and propidium iodide (PI) was prepared and $3 \mu \mathrm{L}$ was added to $1 \mathrm{~mL}$ bacteria suspension, mixed thoroughly, and incubated at room temperature in the dark for $15 \mathrm{~min}$. Five microliters of the stained bacteria suspension was deposited between a glass slide and a coverslip. The slides were observed using a Leica AF6000 LX fluorescent microscope equipped with an Andor iXon 885 Camera and by using an oil immersion objective (100x; 1.4 NA objective). The fluorescence signal was acquired using a dual band excitation and emission filter sets for green fluorescent protein (GFP) and red fluorescent protein (mCherry).

\subsection{Photothermal in Vitro Experiment}

In vitro photothermal ablation tests on parts of fresh pork meat were performed by controlling the power of a LED array $\left(6 \times 6 \mathrm{~mm}^{2}\right.$ in size, $\left.10 \mathrm{~W}, 940 \mathrm{~nm}\right)$ and by controlling the temperature of the meat surface with a thermal forward-looking infrared (FLIR) camera (Seek Thermal, Inc.).

\subsection{In Vivo Photothermal Therapy and Histology}

Studies involving animals, including housing and care, method of euthanasia, and experimental protocols were conducted in accordance with the local animal ethical committee in the animal house (June 24, 2013; protocol 6) of Danylo Halytsky Lviv National Medical University, under the supervision of Dr. R. Bilyy.

Six-week-old male Balb/c mice were used for this investigation. The mice were housed in cages covered with air filters in a temperature-controlled room with a $12 \mathrm{~h} \mathrm{light}$ and $12 \mathrm{~h}$ dark schedule and kept on a standard diet with drinking water available ad libitum. All animal experiments were performed in accordance with institutional ethical guidelines.

Specifically, 11 white laboratory Balb/c mice were evaluated for skin recovery. To establish the surface infection, mouse hair was removed using MedaSept medical depilation cream and a patch of plaster was continuously applied to the area of skin 15 times with the aim to remove the superficial epidermis. Then $10 \mu \mathrm{L}$ of Staphylococcus epidermidis bacterial cell culture containing $2 \times 10^{7} \mathrm{cfu} \mathrm{mL}^{-1}$ was applied and superficial skin infection was allowed to be established for $24 \mathrm{~h}$.(34) After $24 \mathrm{~h}$, mice were anesthetized and sterilized (immersion of the patches into Anios DDSH (ANIOS, France), a cleaning disinfectant for medical devices for 1 h) K/Au NHs (three mice) or K/Au NHs-rGO (five mice) patches were applied to the skin with the rGO layer facing the skin. Finally, three mice were not treated and used as control. The 5

DOI: 10.1021/acsami.7b12949 - Journal: ACS Appl. Mater. Interfaces - Post-print 
patch was illuminated for 5 min with the LED array $\left(6 \times 6 \mathrm{~mm}^{2}\right.$ in size, $\left.10 \mathrm{~W}, 940 \mathrm{~nm}\right)$ and the surface temperature controlled by the FLIR IR camera to be within $50-52{ }^{\circ} \mathrm{C}$ for K/Au NHsrGO and $36-38{ }^{\circ} \mathrm{C}$ for $\mathrm{K} / \mathrm{Au}$ NHs. Mice were photographed with a Nikon camera equipped with Micro-Nikkor objective, from a fixed position and with reference ruler present in each picture. Photos were processed with ImageJ software to detect erythema, and its area before and $24 \mathrm{~h}$ after treatment with patch was evaluated.

Mice were sacrificed after 5 days of treatment. The skin was removed, photographed, and fixed with 4\% neutral buffered formalin solution and embedded in paraffin according to the standard laboratory protocol. The sliced tissues were stained with hematoxylin (for nucleic acids) and eosin (for basic residues, arginines and lysines, on proteins) (H\&E), and Gram stain (for Grampositive bacteria) using routine laboratory procedures.

\section{Results and Discussion}

\subsection{Formation of Nanoholey Photothermal Patches (K/Au NHs)}

Electron beam or focused ion beam lithography are standard methods for the fabrication of well-ordered nanometric holes on various substrates. Next to these highly precise but expensive and time-consuming methods, colloidal lithography is a low-cost and simple alternative.(3032) However, the process is less perfect with local defects being present. This is not limiting given the final application targeted in this study, aiming at developing a flexible interface with plasmonic features absorbing in the near-infrared range. The hole diameter and the center-tocenter spacing of the Au NHs array were adjusted to produce a strong absorption band close to $980 \mathrm{~nm}$ being adapted to plasmonic heating in the near-infrared with a $980 \mathrm{~nm}$ continuous wave laser. In such devices, more than $95 \%$ of the photons from a light source can be absorbed by gold nanostructures and converted into heat via electron-phonon interactions that is subsequently transferred to the surrounding medium via phonon-phonon relaxation in a picosecond time scale. $(35)$

The formation of gold nanoholes on Kapton as substrate (Figure 2A) is based on the selfassembly of polystyrene colloidal spheres with a diameter of $980 \mathrm{~nm}$. The obtained colloidal structures were subjected to plasma etching to reduce the diameter of the spheres and then coated with $2 \mathrm{~nm}$ titanium, to ensure good adhesion, (36) followed by $40 \mathrm{~nm}$ gold. 
(A)

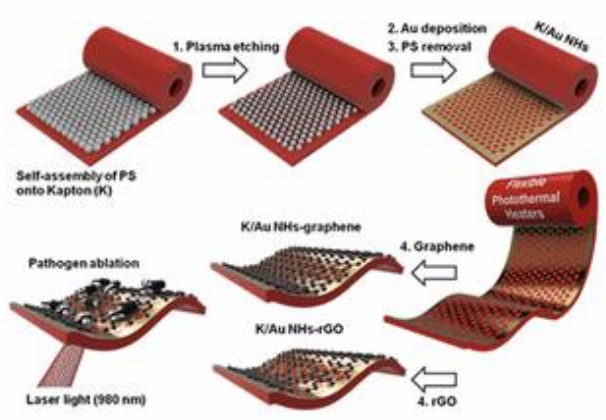

(B)

(C)
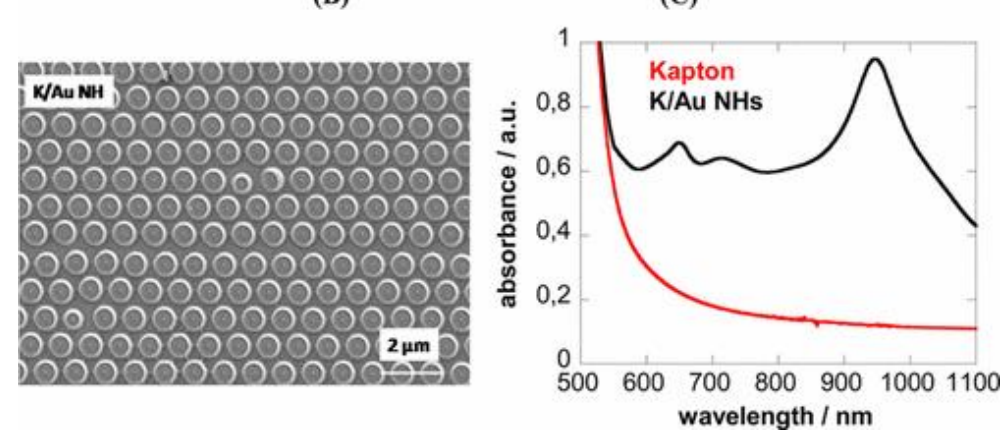

Figure 2. Flexible nanoholey photothermal heaters. (A) Formation of the K/Au NHs interface, postcoated with graphene or rGO for the photothermal ablation of pathogens; (B) SEM image of K/Au NHs formed by using colloidal lithography; (C) typical absorption spectra for Kapton and K/Au NHs samples.

Figure 2B shows a representative SEM image of the K/Au NHs interface. For an etching time of the polystyrene particles of $11 \mathrm{~min}$, highly homogeneous nanoholes with an average diameter of $630 \pm 10 \mathrm{~nm}$ and a center-to-center spacing of $980 \mathrm{~nm}$ are formed in the thin gold film. The long-range ordered gold nanohole array supports both propagating and localized surface plasmon resonance (LSPR) modes, with the hole diameter and periodicity of the Au NHs being important parameters in tuning the absorption band of the interface.(37-40) The absorption spectra of Kapton only and K/Au NHs between 500 and $1100 \mathrm{~nm}$ are depicted in Figure 2C. Kapton alone absorbs strongly below $600 \mathrm{~nm}$ due to its polyimide nature. In the case of K/Au NHs, several absorption bands located at 650,713 , and $950 \mathrm{~nm}$ are observed. While the band at $713 \mathrm{~nm}$ might be associated with the SPR of the water-Au NHs interface, the maximum absorption at $950 \mathrm{~nm}$ occurs through the excitation of SP waves in the nanohole arrays, acting as two-dimensional diffraction gratings that convert incident photons into SP waves. (41)

Figure 3A describes the photothermal properties of the nanoholey patch. In contrast to Kapton with a negligible photothermal effect, irradiation of $\mathrm{K} / \mathrm{Au} \mathrm{NHs}$ under the same conditions results in an elevated average temperature of about $60^{\circ} \mathrm{C}$. 
(A)

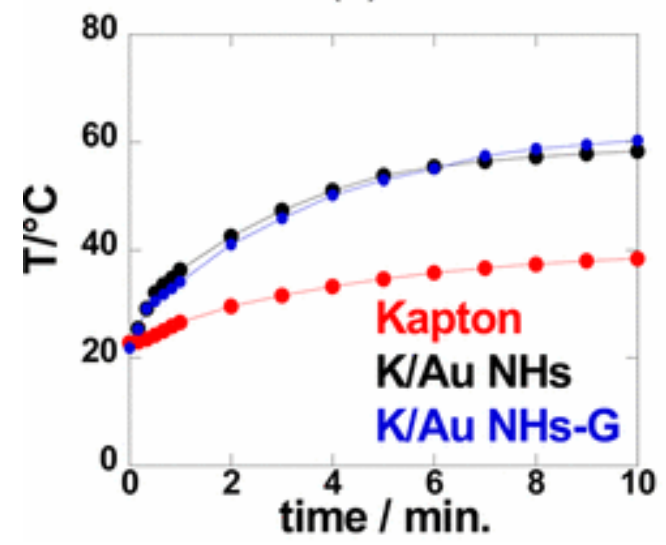

(B)

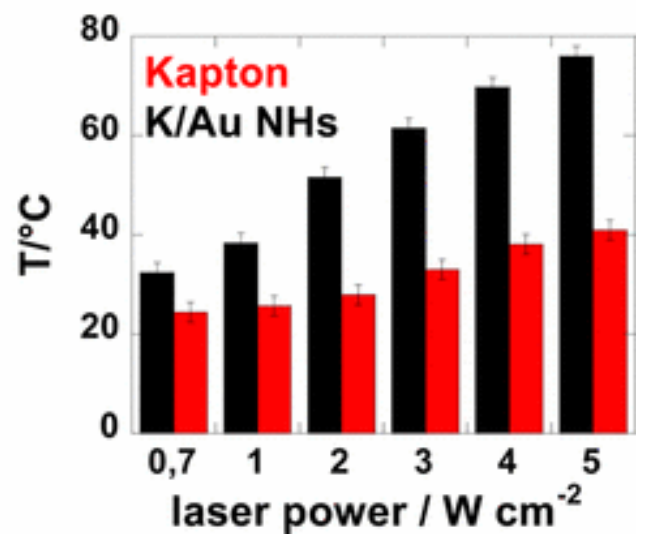

Figure 3. Photothermal properties of flexible nanoholey patches. (A) Photothermal heating curves of Kapton (red) and K/Au NHs (black) and K/Au NHs-G (blue) when immersed in water and exposed to laser light of $980 \mathrm{~nm}$ for $10 \mathrm{~min}$ at $2 \mathrm{~W} \mathrm{~cm}^{-2}$; (B) temperature profile of Kapton and $\mathrm{K} / \mathrm{Au} \mathrm{NH}$ interfaces at different laser power densities recorded after $10 \mathrm{~min}$ irradiation.

For an efficient inactivation of bacteria, temperatures of more than $70{ }^{\circ} \mathrm{C}$ are recommended as this allows inactivation of the bacteria population through cell wall damage and protein denaturation.(7) Using laser power density of $5 \mathrm{~W} \mathrm{~cm}^{-2}$ results in final solution temperatures of $76 \pm 2{ }^{\circ} \mathrm{C}$ (Figure 3B). However, we have shown lately that elevated laser powers result in skin inflammation and skin burning in the worst case. $(42,43)$ With laser power densities $>5 \mathrm{~W}$ $\mathrm{cm}^{-2}$, modification of the skin epidermis structure was noticed, with a total disruption of the stratum corneum collagen cell structure changing to keratin-like (scar tissue).(43)

We thus investigated if postcoating of K/Au NHs with graphene $(\mathrm{G})$ or reduced graphene oxide (rGO) would allow reaching higher temperatures using lower power densities. The K/Au NHsgraphene (K/Au NHs-G) device was formed by mechanical transfer of CVD-grown graphene on $\mathrm{Cu}$ onto the interface. $(7,44)$ Typical SEM and Raman images of K/Au NHs-G can be found in the Supporting Information (Figure S1) and confirm the presence of mono- and multilayers of graphene on K/Au NHs. However, K/Au NHs-G shows no improved photothermal properties over K/Au NHs (Figure 3A). This indicates that for K/Au NHs-G the photothermal heating capacitance is entirely governed by the Au NHs and the submicrometer thick graphene has a marginal additional effect.

Postcoating of K/Au NHs with a solution of $\mathrm{rGO}\left(1 \mathrm{mg} \mathrm{mL}^{-1}\right)$ by drop-casting ( 3 times) results in a K/Au NHs-rGO interface entirely covered with rGO nanoflakes of about $10-1000 \mathrm{~nm}$ in thickness (Figure 4A). These stacked rGO nanoflake coatings show considerable improvement of the photothermal properties, with temperatures reaching $80 \pm 2{ }^{\circ} \mathrm{C}$ after 10 min irradiation at $2 \mathrm{~W} \mathrm{~cm}^{-2}$ (Figure 4B). Interestingly, bending the K/Au NHs-rGO interface does not alter the heating profile (see SI, Figure S2). The interfaces proved to be highly stable over time even when in contact with skin of mice (see section $\underline{3.4}$ ) and no degradation of the photothermal properties were observed upon leaving the interfaces for 3 months either in air or immersed in water, making the interfaces for high interest for practical applications as seen in the following. 
(A)

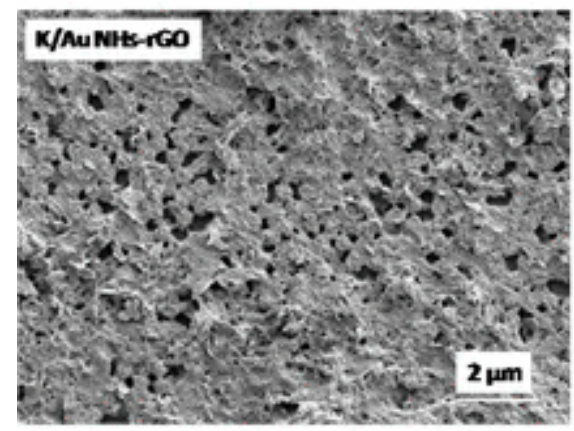

(B)

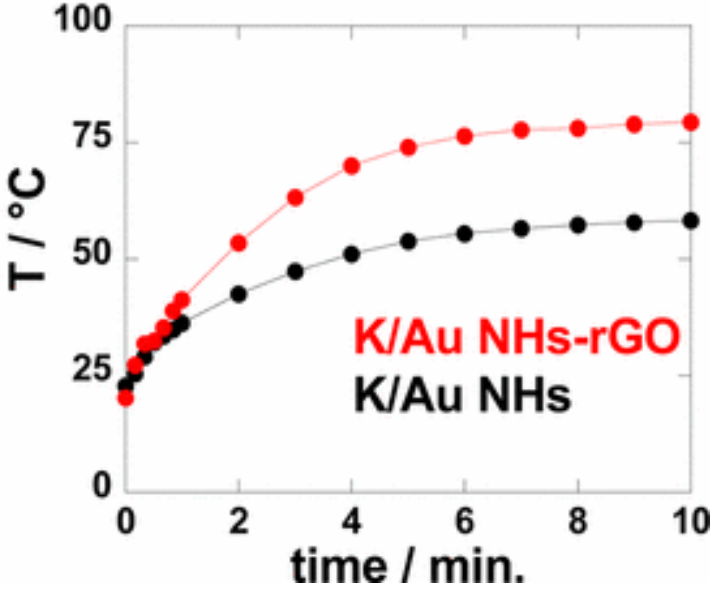

Figure 4. Flexible reduced graphene oxide (rGO)-based heating patches. (A) SEM of rGOcoated K/Au NHs device; (B) photothermal heating curves of K/Au NHs (black) and K/Au NHs-rGO (red) immersed in water and exposed to laser light of $980 \mathrm{~nm}$ for $10 \mathrm{~min}$ at $2 \mathrm{~W} \mathrm{~cm}$ ${ }^{2}$. Error bars were evaluated from the same patch upon 20 different photothermal experiments.

\subsection{Photothermal Ablation of Pathogens Present in Aqueous Solutions}

The development of efficient treatments for biofilm-forming Gram-negative pathogens such as the clinical enteroaggregative Crohn's disease-associated adherent-invasive E. coli LF82 strain, causing severe infections, has proven to be particularly difficult.(45) Enterococcus faecalis, a Gram-positive pathogen from the Streptococcus system, was in addition investigated as it can establish life-threatening infections in humans, especially in hospital environments, where the naturally high levels of antibiotic resistance found in E. faecalis contribute to its resilience to resolution of the infection. Finally, we opted for including Gram-positive S. epidermidis into our investigation. Staphylococci are the most abundant skin-colonizing bacteria and the most significant causes of nosocomial infections and community-associated skin infections.(46) Figure 5A shows the photothermal ablation capacity of the different patches for Gram-positive and Gram-negative planktonic bacteria. 
(A)

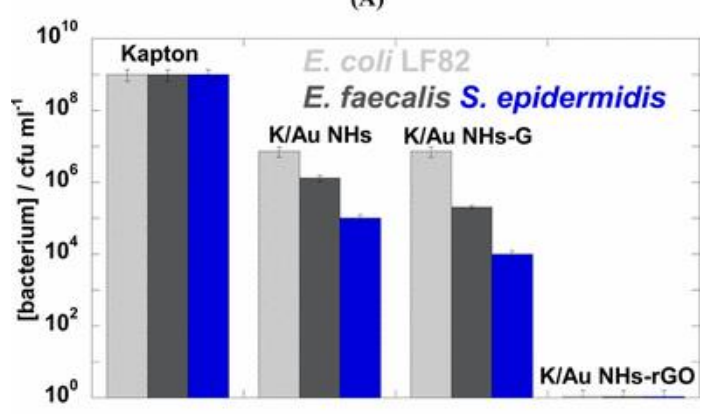

(B)

(C)
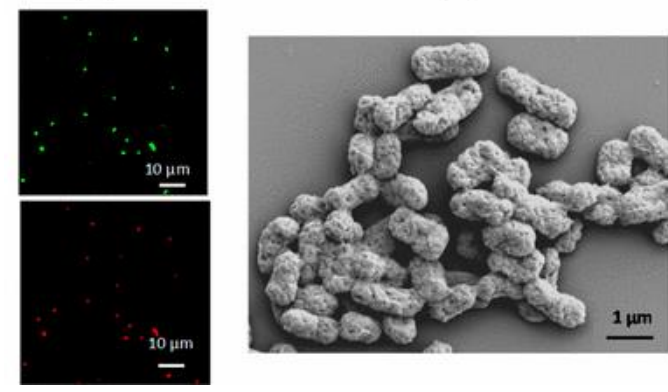

Figure 5. Photothermal bacteria ablation in solution. (A) Bacterial cell viability (in $\mathrm{cfu} \mathrm{mL}^{-1}$ ) of E. coli LF82, E. faecalis, and S. epidermidis upon irradiation of different interfaces at 980 $\mathrm{nm}\left(2 \mathrm{~W} \mathrm{~cm}^{-2}\right)$; (B) dead/live assays total (green) and dead (red) bacteria cell count images of E. coli after photothermal treatment; (C) SEM image of E. coli LF82 after photothermal treatment with K/Au NHs-rGO for $10 \mathrm{~min}\left(980 \mathrm{~nm}, 2 \mathrm{~W} \mathrm{~cm}{ }^{-2}\right)$.

An interface-dependent photothermal pathogen ablation effect was observed (Figure 5A). Kapton alone does not show any photothermal ablation of pathogens. The K/Au NHs patch exhibits about $2 \log _{10}$ (E. coli LF82 and E. faecali) and $3 \log _{10}$ (S. epidermidis) reduction in cell viability of planktonic bacteria after 10 min light activation. In the case of using the K/Au NHs$\mathrm{G}$ architecture, further reduction by $1 \log _{10}$ is noticed for the Gram-positive strains. Using the K/Au NHs-rGO device and laser irradiation for $10 \mathrm{~min}$, a complete photothermal ablation of all three pathogens was observed, being as effective as the antibiotic-loaded gold nanocages reported recently for Staphylococcus aureus.(47) Similar results were reported by Zhu et al. using gold nanorod (Au NR) arrays with optimized density on glass. (48) In this case an array of well-packed Au NRs was formed using the confined convective arraying technique, where the density of the deposited particles is controlled by the concentration of the gold nanorods solution, the velocity of the moving substrate, and the temperature. Only a high concentration of Au NRs, which have to be presynthesized, achieved bacterial mortality rates up to $98 \%$. Our approach, using colloidal lithography to form Au NHs, has the advantage of being highly reproducible and adapted for high-throughput application such as the manufacturing of medical patches to treat skin infections, as discussed here. Live/Dead assays performed on E. coli before and after photothermal treatment with $\mathrm{K} / \mathrm{Au} \mathrm{NHs}-\mathrm{rGO}$ confirms that the cell viability was significantly affected as seen from the high number of red-stained cells (Figure 5B). These results demonstrate that the thermal diffusion, taking place upon irradiation, contributes to heatinduced damage of the bacteria present in the surrounding environment. The SEM image (Figure 5C) suggests in addition that photothermal treatment with K/Au NHs-rGO patches results in the formation of pores in the bacteria cell membrane and subsequent cell death. 


\subsection{Biofilm Formation}

A variety of coatings have been reported to prevent or reduce the formation of pathogenic biofilms. However, most of these films fail to work correctly over a long period of time in biological media such as urine, where bacteria grow rapidly. The capabilities of the different nanoholey interfaces to prevent bacteria attachment were investigated. The SEM images of the surfaces being in contact for $72 \mathrm{~h}$ with the different bacteria (Figure 6) indicate that bacteria are in general not settling spontaneously onto K/Au NHs, while dense bacteria films are formed on $\mathrm{K} / \mathrm{Au} \mathrm{NHs}-\mathrm{G}$ patches and K/Au NHs-rGO patches. This result is in line with the well-accepted concept of the importance of the material surface properties on bacterial adhesion. $(49,50)$ Compared to flat gold, nanostructured gold surfaces have shown to possess excellent antifouling properties, $(51)$ which are believed to be the underlying mechanism for the observed bacteria antifouling properties of K/Au NHs. The bacterial cell wall is negatively charged due to the presence of teichoic acids in the case of Gram-positive bacteria, and in the case of Gramnegative bacteria due to an outer covering of phospholipids and lipopolysaccharides, preferential adhesion to positively charged surfaces are expected.(52) Other adhesion parameters seem to be underlying the interaction between the negatively charged rGO and graphene interfaces with the bacteria.

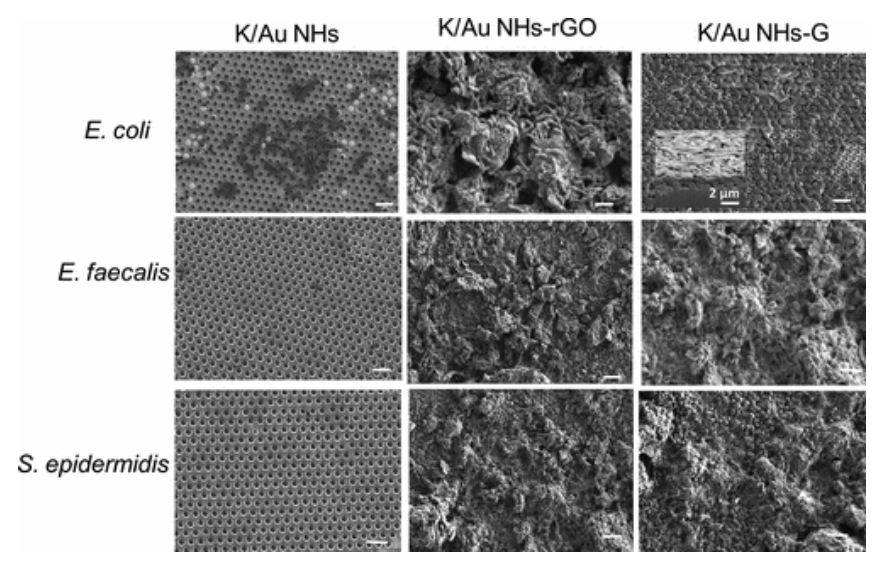

Figure 6. Pathogenic biofilm formation. SEM images of interfaces incubated for $72 \mathrm{~h}$ in E. coli, E. faecalis, and S. epidemidis solutions with initial concentrations of $1 \times 10^{4} \mathrm{cfu} \mathrm{mL}^{-1}$.

\subsection{Treatment of Subcutaneous Skin Infections}

4. To test the possibility of photothermal therapy of superficial skin infections in vivo, we first determined the level of living tissue heating by applying sterilized K/Au NHs-rGO to the surface of raw pork meat and determining the surface temperature with a FLIR camera by irradiating the tissue with a $940 \mathrm{~nm}\left(2 \mathrm{~W} \mathrm{~cm}^{-2}\right)$ LED microarray. Sterilization of the patch was performed upon immersion of the patches into Anison for $1 \mathrm{~h}$. The used LED microarray allows for a uniform irradiation of a $2 \times 2 \mathrm{~cm}^{2}$ surface area. As heating above $55^{\circ} \mathrm{C}$ caused visible denaturation of muscle tissue ("burns"), the LED power was adjusted to maintain surface heating at around $50{ }^{\circ} \mathrm{C}$, where no visible damage was observed after 10 min irradiation (see Supporting Information, Figure S3).

5. To test the potential of K/Au NHs-rGO patches $\left(1 \times 2 \mathrm{~cm}^{2}\right.$ in size $)$ in combination with the LED microarray to treat local skin infections, white laboratory Balb/c mice were infected and used for photothermal studies. First, mouse hairs were removed on the back and the 
K/Au NHs-rGO patch was applied to the shaved skin (Figure 7). The next day, a bacterial suspension was applied topically which developed into an infected wound within $24 \mathrm{~h}$.

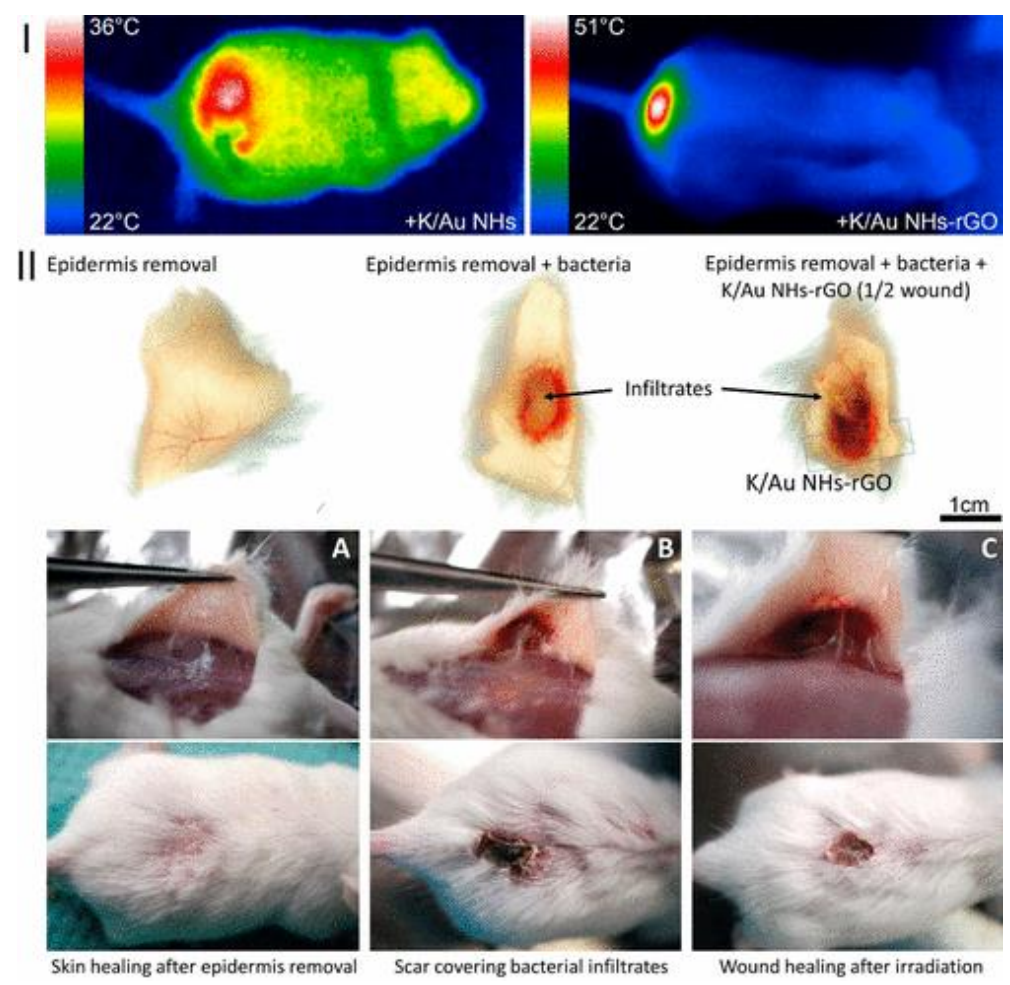

Figure 7. In vivo photothermal therapy of skin infections initiated in mice with K/Au NHsrGO patches. (I) Thermal images of mice heated with either K/Au NHs (max. temperature $\sim 36{ }^{\circ} \mathrm{C}$, left) or $\mathrm{K} / \mathrm{Au} \mathrm{NHs}-\mathrm{rGO}$ (max. temperature $\sim 51{ }^{\circ} \mathrm{C}$, right) demostrate uniform heat distribution in the irradiated area. (II) Photographs of mouse skin before (A) and after 5 days of infection (B and $\mathrm{C}$ ) without and with laser illumination. A mouse undergoing only epidermis damage showing no visible signs of skin damage (A), while initiation of infection resulted in prominent bacterial infiltrate (B). Infected epidermae after illumination for $10 \mathrm{~min}$ with a LED array through the K/Au NHs-rGO skin patch show no bacterial infiltration and active tissue restoration $(\mathrm{C})$.

This early state infection was treated with the K/Au NHs-rGO patch upon irradiation for 10 min. Thereafter, the infected wound surface was monitored for 5 days upon which the mice were sacrificed and a portion of skin around the infected area was removed, photographed, and subjected to histological analysis (Figures 8 and 9). After 5 days of infection initiation, superficial bacterial infiltrate was observed (Figure 7); however, in the place of contact with the patch no obvious infiltrate was detected. To quantitatively estimate the skin recovery of infected mice under the action of K/Au NHs-rGO as well as the multiple uses of a patch, 11 white laboratory Balb/c mice were evaluated for skin recovery using the same patch. Figure 8 summarizes the results of these experiments. The images obtained of the infected skin area before and $72 \mathrm{~h}$ after treatment using the K/Au NHs-rGO patche show a clear and significant decrease in detected erythema when compared to untreated and K/Au NHs-treated wounds, indicating the advantage of this treatment procedure. 


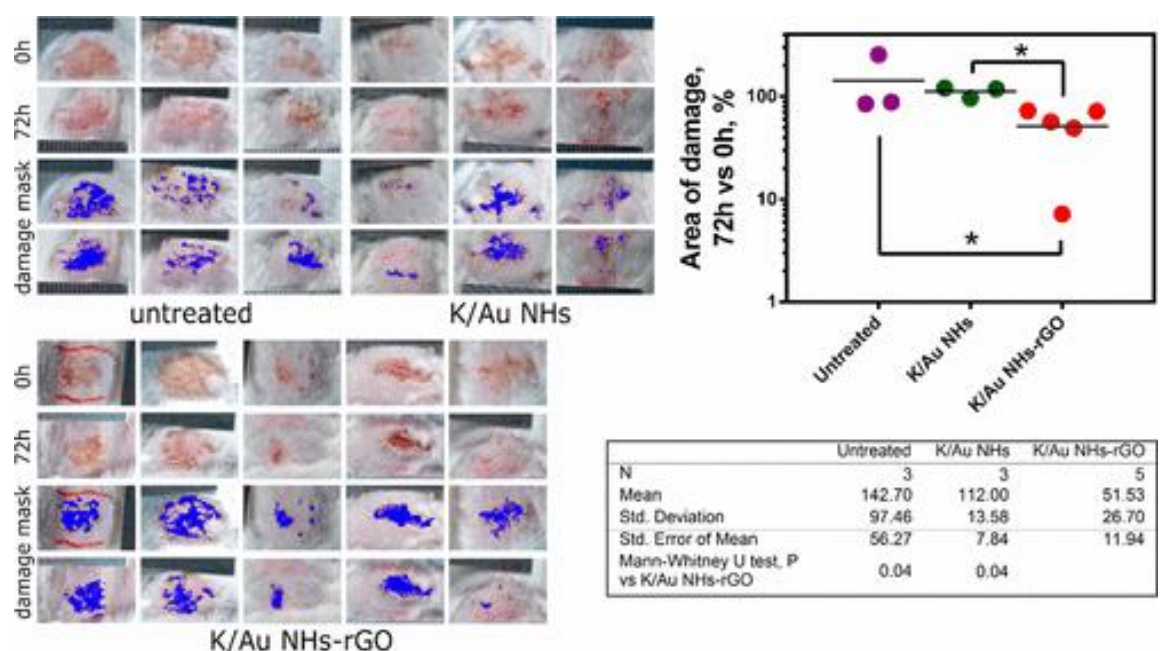

Figure 8. Quantification of mouse skin erythema. Skin analysis before and $72 \mathrm{~h}$ after treatment with K/Au NHs and K/Au NHs-rGO patch: (left) Photographs of mouse skin indicating infected areas; (right) determination of average skin damage after $72 \mathrm{~h}$ under different treatment conditions together with statistical analysis.

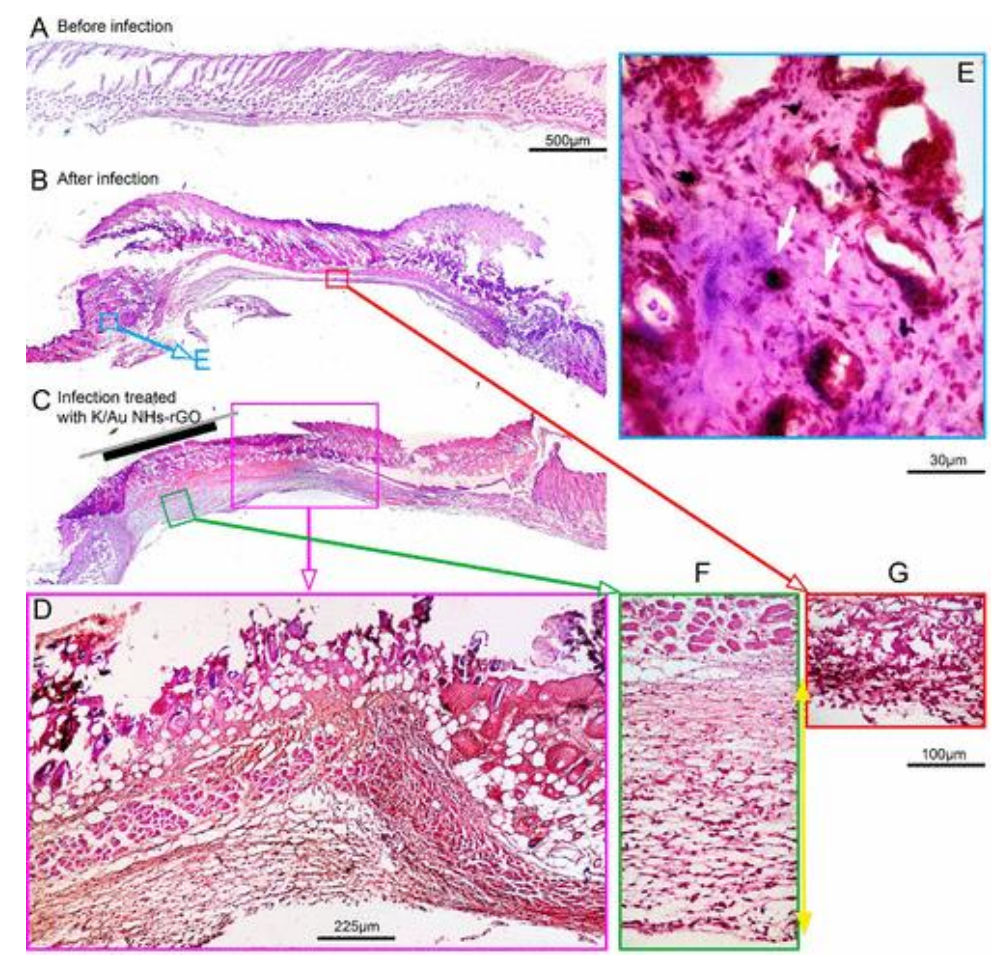

Figure 9. Histological analysis of mouse skin with longitudinal section across the wound and scar tissue. (A) Skin before infection. (B) Skin after infection. (C) Skin after infection with photothermally treated part of wound. (D) Interface between irradiated and nonirradiated tissue clearly showing abundant formation of granulation tissue beneath the heated area; (E) leukocyte and bacterial infiltration at the edge of the wound, where the tissue still was not converted to pus; ( $F$ and $\mathrm{G}$ ) heated and unheated areas of infection demonstrating granulation tissue (marked with yellow arrow) attributable to wound healing, located beneath the layer of muscle (aligned 13

DOI: 10.1021/acsami.7b12949 - Journal: ACS Appl. Mater. Interfaces - Post-print 
at the top, to the same scale). Heated area shows viable muscular fiber and abundant granulation tissue, while the nonheated area possesses necrotic muscular fibers and puslike infiltrate beneath it. (A-C) H\&E staining. (D-G) Gram staining. D-G are corresponding enlarged areas of parallel slides indicated by color.

Histological analysis revealed that bacterial infection caused prominent skin damage beneath the scar covering the wound (Figure 9). This is accompanied by complete destruction of the epidermal, dermis layer and underlying muscles. In addition, bacterial and leukocytic infiltration is abundant (Figure 9E). At the same time the infected wound illuminated through the K/Au NHs-rGO patch for 10 min showed only traces of bacterial infiltration, with granulation tissue abundantly formed beneath the muscular layer, suggesting active wound healing. Indeed, at the interface between the treated and the nontreated wound, prominent granulation tissues are seen where the patch was present (Figure 9F), while the penetrating bacterial infection, accompanied by tissue necrosis, is clearly visible for areas without illumination.

\section{Conclusion}

In summary, this work proposes a novel nanotechnology approach for the local healing of infected skin wounds at early stages. The strategy consists of using a flexible skin patch of variable size based on Kapton modified with gold nanoholes that exhibit plasmon-driven heat capacity in the NIR. While in this work skin patches of $1 \times 1 \mathrm{~cm}^{2}$ in size were used, the technology is easily adaptable to larger, relevant sizes for the treatment of wounded skin. Postcoating of these patches with rGO enhances the observed photothermal behavior. Moreover, these fabricated interfaces are highly stable over time, ensuring safe use as functional skin patches. The bactericidal activity of the patch can be modulated and turned on and off using light. The highly efficient photothermal conversion of the patch resulted in total eradication of Gram positive and Gram negative pathogens in solution. The device was further used for the local treatment of mice with infected skin wounds. Without the addition of any antibiotic, wound healing was observed upon placing the K/Au NHs-rGO patch over the wound and irradiating for $10 \mathrm{~min}$. The thickness of the rGO layer $(10-1000 \mathrm{~nm})$ deposited onto the $\mathrm{Au}$ NHs array did not influence in any significant manner the healing process. As thinner rGO films proved to be mechanically more stable, thin rGO coatings are advantageous for this application. Indeed, rGO layers of about $<100 \mathrm{~nm}$ in thickness were used more than 10 times without any loss in bactericidal activity upon light illumination. This approach opens new avenues to wound management and the treatment of patients with subcutaneous infections. The reusability of the patch, together with the possibility to sterilize it, recommend this method as cost-effective and, thus, potentially marketable. Furthermore, convenient patch usage rather than injection of nanostructures for photothermal pathogen treatment makes this approach a safe and highly attractive alternative as the toxicity of the nanostructures is of no concern here. This modus operando might allow personalized treatment of skin infections in a nonclinical setting.

\section{Acknowledgements}


Financial supports from the Centre National de la Recherche Scientifique (CNRS), the University Lille 1, the Hauts-de-France region, the CPER "Photonics for Society", the Agence National de la Recherche (ANR) through FLAG-ERA JTC 2015-Graphtivity, and the EU union through the Marie Sklodowska-Curie action (H2020-MSCA-RISE-2015, PANG-690836) are acknowledged. The work was supported by the Belgian F.R.S. - FNRS in the frame of the research conventions no. T.1004.14 - ECOSTOFLEX project and no. R 50.02.16.F - FLAGERA JTC 2015-Graphtivity project.

\section{References}

1. Martin, P. Wound Healing-Aiming for Perfect Skin Regeneration Science 1997, 276, 75-81 DOI: $10.1126 /$ science.276.5309.75

2. Szunerits, S.; Boukherroub, R. Antibacterial Activity Of Graphene-Based Materials J. Mater. Chem. B 2016, 4, 6892- 6912 DOI: 10.1039/C6TB01647B

3. Bilyy, R.; Fedorov, V.; Vovk, V.; Leppkes, M.; Dumych, T.; Chopyak, V.; Schett, G.; Herrmann, M. Neutrophil Extracellular Traps Form a Barrier between Necrotic and Viable Areas in Acute Abdominal Inflammation Front. Immunol. 2016, 7, 424 DOI: 10.3389/fimmu.2016.00424

4. Ellis, S. L.; Finn, P.; Noone, M.; Leaper, D. J. Eradication Of Methicillin-Resistant Staphylococcus Aureus From Pressure Sores Using Warming Therapy Surg. Infect. (Larchmt) 2003, 4, 53- 55 DOI: 10.1089/109629603764655281

5. Khan, A. A.; Banwell, P. E.; Bakker, M. C.; Gillespie, P. G.; McGrouther, D. A.; Roberts, A. H. N. Topical Radiant Heating In Wound Healing: An Experimental Study In A Donor Site Wound Model Int. Wound J. 2004, 1, 233- 240 DOI: 10.1111/j.17424801.2004.00065.x

6. Wu, M. C.; Deokar, A. R.; Liao, J. H.; Shih, P. Y.; Ling, Y. C. Graphene-Based Photothermal Agent For Rapid And Effective Killing Of Bacteria ACS Nano 2013, 7, 1281- 1290 DOI: 10.1021/nn304782d

7. Turcheniuk, K.; Hage, C.-H.; Spadavecchia, J.; Serrano, A. Y.; Larroulet, I.; Pesquera, A.; Zurutuza, A.; Pisfil, M. G.; Heliot, L.; Bouckaert, J.; Boukherroub, R.; Szunerits, S. Plasmonic Photothermal Destruction Of Uropathogenic E. Coli With Reduced Graphene Oxide And Core/Shell Nanocomposites Of Gold Nanorods/Reduced Graphene Oxide J. Mater. Chem. B 2015, 3, 375- 386 DOI: 10.1039/C4TB01760A

8. Lee, E. S.; Caldwell, M. P.; Talarico, P. J.; Kuskowski, M. A.; Santilli, S. M. Use Of A Noncontact Radiant Heat Bandage On Staphylococcus Aureus Dermal Infection In An Ovine Model Wound Repair Regen. 2000, 8, 562- 566 DOI: 10.1046/j.1524475x.2000.00562.x

9. Chiang, X.-L.; Lin, T.-T.; Sureshbabu, R.; Chia, W.-T.; Hsiao, H.-C.; Liu, H.-Y.; Yang, C.-M.; Sung, H.-W. A Rapid Drug Release System With A Nir Light-Activated Molecular Swith For Dual-Modalioty Photothermal/Antibiotic Treatments Of Subcutaneous Absesses J. Controlled Release 2015, 199, 53- 62 DOI: 10.1016/j.jconrel.2014.12.011

10. Yousefi, M.; Dadashpour, M.; Hejazi, M.; Hasanzadeh, M.; Behnam, B.; de la Guardia, M.; Shadjou, N.; Mokhtarzadeh, A. Anti-Bacterial Activity Of Graphene Oxide As A 
New Weapon Nanomaterial To Combat Multidrug-Resistance Bacteria Mater. Sci. Eng., C 2017, 74, 568- 581 DOI: 10.1016/j.msec.2016.12.125

11. Hui, L.; Huang, J.; Chen, G.; Zhu, Y.; Yang, L. Antibacterial Property Of Grpahene Quantum Dots (Both Source Material And Bacterial Shape Matter) ACS Appl. Mater. Interfaces 2016, 8, 20- 25 DOI: 10.1021/acsami.5b10132

12. Zhao, J.; Deng, B.; Lv, M.; Li, J.; Zhang, Y.; Jiang, H.; Peng, C.; Li, J.; Shi, J.; Huang, Q.; Fan, C. Graphene Oxide-Based Antibacterial Cotton Fabrics Adv. Healthcare Mater. 2013, 2, 1259- 1266 DOI: 10.1002/adhm.201200437

13. Sun, H.; Gao, N.; Dong, K.; Ren, J.; Qu, X. Graphene Quantum Dots-Bad-Aids Used For Wound Disinfection ACS Nano 2014, 8, 6202- 6210 DOI: 10.1021/nn501640q

14. Ray, P. C.; Khan, S. A.; Singh, A. K.; Senapati, D.; Fan, Z. Nanomaterials For Targetted Detection And Photothermal Killing Of Bacteria Chem. Soc. Rev. 2012, 41, 3193-3209 DOI: $10.1039 / \mathrm{c} 2 \mathrm{cs} 15340 \mathrm{~h}$

15. Tsai, M.-F.; Chang, S.-H. G.; Cheng, F.-Y.; Shanmugam, V.; Cheng, Y.-S.; Su, C.-H.; Yeh, C.-S. Au Nanorod Design as Light-Absorber in the First and Second Biological Near-Infrared Windows for in Vivo Photothermal Therapy ACS Nano 2013, 7, 5330 5342 DOI: $10.1021 / \mathrm{nn} 401187 \mathrm{c}$

16. Teng, C. P.; Zhou, T.; Ye, E.; Liu, S.; Koh, L. D.; Low, M.; Loh, X. J.; Win, K. Y.; Zhang, L.; Han, M.-Y. Effective Targeted Photothermal Ablation of Multidrug Resistant Bacteria and Their Biofilms with NIR-Absorbing Gold Nanocrosses Adv. Healthcare Mater. 2016, 5, 2122-2130 DOI: 10.1002/adhm.201600346

17. Haine, A. T.; Koga, Y.; Hashimoto, Y.; Higashi, T.; Motoyama, K.; Arima, H.; Niidome, T. Enhancement Of Transdermal Protein Delivery By Photothermal Effect Of Gold Nanorods Coated On Polysaccharide-Based Hydrogel Eur. J. Pharm. Biopharm. 2017, 119, 91-95 DOI: 10.1016/j.ejpb.2017.06.005

18. Chen, D.; Wu, M.; Chen, J.; Zhang, C.; Pan, T.; Zhang, B.; Tian, H.; Chen, X.; Sun, J. Robust, Flexible, and Bioadhesive Free-Standing Films for the Co-Delivery of Antibiotics and Growth Factors Langmuir 2014, 30, 13898- 13906 DOI: 10.1021/la503684k

19. Chen, D.; Chen, J.; Wu, M.; Tian, H.; Chen, X.; Sun, J. Robust and Flexible FreeStanding Films for Unidirectional Drug Delivery Langmuir 2013, 29, 8328- 8334 DOI: 10.1021/la401423d

20. Yin, Y.; Alivisatos, A. P. Colloidal Nanocrystal Synthesis And The Organic-Inorganic Interface Nature 2005, 437, 664- 670 DOI: 10.1038/nature04165

21. Webb, R. C.; Bonifas, A. P.; Behnaz, A.; Zhang, Y.; Yu, K. J.; Cheng, H.; Shi, M.; Bian, Z.; Liu, Z.; Kim, Y.-S.; Yeo, W.-H.; Park, J. S.; Song, J.; Li, Y.; Huang, Y.; Gorbach, A. M.; Rogers, J. A. Ultrathin Conformal Devices For Precise And Continous Thermal Characterisaiton Of Human Skin Nat. Mater. 2013, 12, 938- 944 DOI: 10.1038/nmat3755

22. Baffou, G.; Berto, P.; Bermúdez Ureña, E. B.; Quidant, R.; Monneret, S.; Polleux, J.; Rigneault, H. Photoinduced Heating of Nanoparticle Arrays ACS Nano 2013, 7, 6478 6488 DOI: $10.1021 / \mathrm{nn} 401924 \mathrm{n}$

23. Tordera, D.; Zhao, D.; Volkov, A. V.; Crispin, X.; Jonsson, M. P. Thermoplasmonic Semitransparent Nanohole Electrodes Nano Lett. 2017, 17, 3145- 3151 DOI: 10.1021/acs.nanolett.7b00574

24. Virk, M.; Xiong, K.; Svedendahl, M.; Käll, M.; Dahlin, A. B. A Thermal Plasmonic Sensor Platform: Resistive Heating of Nanohole Arrays Nano Lett. 2014, 14, 35443549 DOI: $10.1021 / \mathrm{n} 15011542$ 
25. Brolo, A. G.; Kwok, S. C.; Moffitt, M. G.; Gordon, R.; Riordon, J.; Kavanagh, K. L. Enhanced Fluorescence from Arrays of Nanoholes in a Gold Film J. Am. Chem. Soc. 2005, 127, 14936- 14941 DOI: 10.1021/ja0548687

26. Rindzevicius, T.; Alaverdyan, Y.; Sepulveda, B.; Pakizeh, T.; Käll, M.; Hillenbrand, R.; Aizpurua, J.; García de Abajo, J. J. Nanohole Plasmons in Optically Thin Gold Films J. Phys. Chem. C 2007, 111, 1207- 1212 DOI: 10.1021/jp065942q

27. Yang, J.-C.; Ji, J.; Hogle, J. M.; Larson, D. N. Metallic Nanohole Arrays on Fluoropolymer Substrates as Small Label-Free Real-Time Bioprobes Nano Lett. 2008, 8, 2718- 2724 DOI: 10.1021/nl801043t

28. Wang, X.; Lu, X.; Liu, B.; Chen, D.; Tong, Y.; Shen, G. Flexible Energy-Storage Devices: Design Consideration And Recent Progress Adv. Mater. 2014, 26, 4763- 4782 DOI: $10.1002 /$ adma.201400910

29. Xiao, Y.; Low, B. T.; Hosseini, S. S.; Chung, T. S.; Paul, D. R. The Strategies Of Molecular Architecture And Modification Of Polyimide-Based Membranes For $\mathrm{Co}_{2}$ Removal From Natural Gas-A Review Prog. Polym. Sci. 2009, 34, 561- 580 DOI: 10.1016/j.progpolymsci.2008.12.004

30. Qi, J.; Motwani, P.; Gheewala, M.; Brennan, C.; Wolfe, J. C.; Shih, W.-C. SurfaceEnhanced Raman Spectroscopy With Monolithic Nanoporous Gold Disk Substrates Nanoscale 2013, 5, 4105-4109 DOI: 10.1039/c2nr33242f

31. Santos, G. M.; Zhao, F.; Zeng, J.; Shih, W.-C. Characterization Of Nanoporous Gold Disks For Photothermal Light Harvesting And Light-Gated Molecular Release Nanoscale 2014, 6, 5718- 5724 DOI: 10.1039/C4NR01266F

32. Zhang, J.-T.; Wang, L.; Lamont, D. N.; Velankar, S. S.; Asher, S. A. Fabrication Of Large-Area Two-Dimensional Colloidal Crystals Angew. Chem., Int. Ed. 2012, 51, 6117-6120 DOI: 10.1002/anie.201105439

33. Li, X.; Cai, W.; An, J.; Kim, S.; Nah, J.; Yang, D.; Piner, R.; Velamakanni, A.; Jung, I.; Tutuc, E.; Banerjee, S. K.; Colombo, L.; Ruoff, R. S. Large-Area Synthesis Of HighQuality And Uniform Graphene Films On Copper Foils Science 2009, 324, 1312- 1314 DOI: $10.1126 /$ science. 1171245

34. Kugelberg, E.; Norstrom, T.; Petersen, T. K.; Duvold, T.; Andersson, D. I.; Hughes, D. Establishment Of A Superficial Skin Infection Model In Mice By Using Staphylococcus Aureus And Streptococcus Pyogenes Antimicrob. Agents Chemother. 2005, 49, 34353441 DOI: 10.1128/AAC.49.8.3435-3441.2005

35. El-Sayed, M. A. Some Interesting Properties Of Metals Confined In Time And Nanometer Space Of Different Shapes Acc. Chem. Res. 2001, 34, 257- 264 DOI: 10.1021/ar960016n

36. Putz, B.; Schoeppner, R. L.; Glushko, O.; Bahr, D. F.; Cordill, M. J. Improved electromechanical performance of gold films on polyimide without adhesion layers Scr. Mater. 2015, 102, 23- 26 DOI: 10.1016/j.scriptamat.2015.02.005

37. Couture, M.; Liang, Y.; Poirier Richard, H.-P.; Faid, R.; Peng, W.; Masson, J.-F. Tuning The 3d Plasmon Field Of Nanohole Arrays Nanoscale 2013, 5, 12399- 12408 DOI: $10.1039 / \mathrm{c} 3 \mathrm{nr} 04002 \mathrm{j}$

38. Nishida, M.; Hatakenaka, N.; Kadoya, Y. Multipole Surface Plasmons In Metallic Nanohole Arrays Phys. Rev. B: Condens. Matter Mater. Phys. 2015, 91, 235406 DOI: 10.1103/PhysRevB.91.235406

39. Schwind, M.; Kasemo, B.; Zoric, I. Localized And Propagating Plasmons In Metal Films With Nanoholes Nano Lett. 2013, 13, 1743-1750 DOI: 10.1021/nl400328x 
40. Lesuffleur, A.; Im, H.; Lindquist, N. C.; Oh, S. H. Periodic Nanohole Arrays With Shape-Enhanced Plasmon Resonance As Real-Time Biosensors Appl. Phys. Lett. 2007, 90, 243110 DOI: $10.1063 / 1.2747668$

41. Cheng, K.; Wang, S.; Cui, Z.; Li, Q.; Dai, S.; Du, Z. Large-Scale Fabrication Of Plasmonic Gold Nanohole Arrays For Refractive Index Sensing At Visible Region Appl. Phys. Lett. 2012, 100, 253101 DOI: 10.1063/1.4728987

42. Teodorescu, F.; Quéniat, G.; Foulon, C.; Lecoeur, M.; Barras, A.; Boulahneche, S.; Medjram, M. S.; Hubert, T.; Abderrahmani, A.; Boukherroub, R.; Szunerits, S. Transdermal Skin Patch Based On Reduced Graphene Oxide: A New Approach For Photothermal Triggered Permeaetion Of Ondansetron Across Porcin Skin J. Controlled Release 2017, 245, 137- 146 DOI: 10.1016/j.jconrel.2016.11.029

43. Teodorescu, F.; Oz, Y.; Quéniat, G.; Abderrahmani, A.; Foulon, C.; Lecoeur, M.; Sanyal, R.; Sanyal, A.; Boukherroub, R.; Szunerits, S. Photothermally triggered OnDemand Insulin Release from Reduced Graphene Oxide modified Hydrogels $\mathrm{J}$. Controlled Release 2017, 246, 164- 173 DOI: 10.1016/j.jconrel.2016.10.028

44. Zagorodko, O.; Spadavecchia, J.; Serrano, A. Y.; Larroulet, I.; Pesquera, A.; Zurutuza, A.; Boukherroub, R.; Szunerits, S. Highly Sensitive Detection of DNA Hybridization on Commercialized Graphene-Coated Surface Plasmon Resonance Interfaces Anal. Chem. 2014, 86, 11211-11216 DOI: 10.1021/ac502705n

45. Rendueles, O.; Beloin, C.; Latour-Lambert, P.; Ghigo, J.-M. A new biofilmassociated colicin with increased efficiency against biofilm bacteria ISME J. 2014, 8, 1275- 1288 DOI: 10.1038 ismej.2013.238

46. Otto, M. Staphylococcus Colonization Of The Skin And Antimicrobial Peptides Expert Rev. Dermatol. 2010, 5, 183-195 DOI: 10.1586/edm.10.6

47. Meeker, D. G.; Jenkins, S. V.; Miller, E. K.; Beenken, K. E.; Loughran, A. J.; Powless, A.; Muldoon, T. J.; Galanzha, E. I.; Zharov, V. P.; Smeltzer, M. S.; Chen, J. Synergistic Photothermal and Antibiotic Killing of Biofilm-Associated Staphylococcus aureus Using Targeted Antibiotic-Loaded Gold Nanoconstructs ACS Infect. Dis. 2016, 2, 241250 DOI: 10.1021/acsinfecdis.5b00117

48. Zhu, Y.; Ramasamy, M.; Yi, D. K. Antibacterial Activity of Ordered Gold Nanorod Arrays ACS Appl. Mater. Interfaces 2014, 6, 15078- 15085 DOI: 10.1021/am503153v

49. Svensson, S.; Forsberg, M.; Hulander, M.; Vazirisani, F.; Palmquist, A.; Lausmaa, J.; Thomsen, P.; Trobos, M. Role Of Nanostructured Gold Surfaces On Monocyte Activation And Staphylococcus Epidermidis Biofilm Formation Int. J. Nanomed. 2014, 9, 775- 794 DOI: 10.2147/IJN.S51465

50. Parreira, P.; Magalhães, A.; Gonçalves, I. C.; Gomes, J.; Vidal, R.; Reis, C. A.; Leckband, D. E.; Martins, M. C. L. Effect Of Surface Chemistry On Bacterial Adhesion, Viability, And Morphology J. Biomed. Mater. Res., Part A 2011, 99, 344- 353 DOI: 10.1002/jbm.a.33178

51. Joshi, S.; Pellacani, P.; van Beek, T. A.; Zuilhof, H.; Nielen, M. W. F. Surface Characterization And Antifouling Properties Of Nanostructured Gold Chips For Imaging Surface Plasmon Resonance Biosensing Sens. Actuators, B 2015, 209, 505514 DOI: 10.1016/j.snb.2014.11.133

52. Khantamat, O.; Li, C. H.; Yu, F.; Jamison, A. C.; Shih, W.-C.; Cai, C.; Lee, T. R. Gold Nanoshell-Decorated Silicone Surfaces For The Near-Infrared (Nir) Photothermal 
Destruction Of The Pathogenic Bacterium E. Faecalis ACS Appl. Mater. Interfaces 2015, 7, 3981- 3993 DOI: 10.1021/am506516r 